\title{
INTERPRETASI PROMOSI SECARA PERSONAL SELLING DALAM EKSPLANASI PENJUALAN PRODUK SIARAN TELEVISI DIGITAL PT. SIBAYAK ENTERTAINMENT INDONESIA
}

\author{
Agus N. Simanjuntak ${ }^{1}$ Anita Tresia Samosir ${ }^{2}$ Desi N. Hutahaean ${ }^{3}$ \\ Fakultas Ekonomi dan Bisnis Universitas HKBP Nommensen \\ agus.nakkok@yahoo.com
}

\begin{abstract}
ABSTRAK: PT. Sibayak Entertainment merupakan perusahaan yang memasarkan siaran televisi yang berlangganan penyiaran secara prabayar dengan satelit K-Vision secara digital melalui Kompas Gramedia Televison Group. Pemasaran dilakukan secara Personal Selling atau dengan tujuan agar pemasaran siaran televisi dapat dilakukan dua arah dan dianggap lebih efektif dalam memasarkan produk, karena tujuan akhir adalah penjualan. Penelitian ini dilakukan menggunakan metode deskriptif analisis kualitatif berdasarkan hasil skor kuesioner dengan mengumpulkan skor dari kuesioner, diolah secara rekapitulasi skor, secara skor ideal dan secara persentase skor terhadap responden dalam hal ini personal selling dan capaian penjualan siaran TV digital di Kabupaten Karo Propinsi Sumatera Utara. PT. Sibayak Entertainment Indonesia dengan personal selling mempunyai pengaruh paling besar terhadap capaian penjualan, dengan jumlah sampel sebanyak 50 orang responden. Berdasarkan penelitian yang telah dilakukan menggunakan hasil jawaban responden, $80 \%$ sampai $90 \%$ responden memberikan jawaban setuju dan sangat setuju, sisanya masih terdapat tidak setuju dan sangat tidak setuju dengan promosi menggunakan personal selling demikian pula dengan capaian penjualan. Dengan menggunakan rekapitulasi dan persentase kekuatan dan kelemahan, personal selling dan capaian penjualan berada pada kategori kuat dan sangat kuat. Hal ini menunjukkan bahwa PT. Sibayak Entertainment Indonesia sudah memilih langkah promosi yang baik dengan menggunakan personal selling karena menunjukkan capaian penjualan yang baik dan target penjualan dapat tercapai sesuai dengan yang ditentukan perusahaan.
\end{abstract}

\section{Kata Kunci : Rekapitulasi Skor dan Persentase Hasil Rekapitulasi Skor}

\begin{abstract}
PT. Sibayak Entertainment is a company that markets television broadcasts that subscribe to broadcasting on a prepaid basis with K-Vision satellite digitally through Kompas Gramedia Televison Group. Marketing is carried out by personal selling or with the aim that television broadcast marketing can be carried out in two directions and is considered more effective in marketing products, because the final goal is sales.

This research was conducted using a descriptive qualitative analysis method based on the results of the questionnaire scores by collecting scores from the questionnaire, processed by recapitulation scores, ideally scores and percentage scores of respondents in this case personal selling and sales achievement of digital TV broadcasts in Karo Regency, North Sumatra Province.

PT. Sibayak Entertainment Indonesia with personal selling has the greatest influence on sales achievement, with a total sample of 50 respondents.

Based on research that has been done using the results of respondents' answers, $80 \%$ to $90 \%$ of respondents gave answers agree and strongly agree, the rest there are still disagree and strongly disagree with promotions using personal selling as well as sales achievements.

By using the recapitulation and percentage of strengths and weaknesses, personal selling and sales achievements are in the strong and very strong categories.

This shows that PT. Sibayak Entertainment Indonesia has chosen a good promotion step by using personal selling because it shows good sales achievements and sales targets can be achieved as determined by the company.
\end{abstract}

Keywords: Score Recapitulation and Percentage of Score Recapitulation Results 
Menurut Kotler dan Keller (2009:1) keputusan yang benar tentang perubahan tidak selalu mudah, para manajer pemasaran harus memutuskan fitur apa yang harus diciptakan pada produk, harga yang ditawarkan kepada pelanggan, dimana mereka harus menjual produk, dan beberapa jumlah anggaran yang harus dihabiskan untuk iklan, penjualan, atau internet. Mereka juga harus memutuskan detail seperti kata-kata, warna yang tepat untuk kemasan dan jenis produk yang dipasarkan. Perusahaaan akan menanggung risiko besar adalah bila perusahaan tidak memantau pelanggan dan pesaingnya dengan cermat, tidak terus meningkatkan nilai tambah yang ditawarkan ke pelanggan. Perusahan selalu memandang bisnis dari sudut jangka pendek yang hanya digerakkan oleh penjualan dan akhirnya gagal memuaskan pemegang saham, karyawan, pemasok, dan mitra saluran mereka.

Pada saat ini banyak jenis produk dan jasa yang ditawarkan di pasar, sehingga konsumen tidak lagi tergantung kepada satu merek saja. Agar produk yang ditawarkan atau dijual dapat sampai dan diketahui serta dibeli oleh konsumen dan menjadi pelanggan maka diperlukan strategi promosi pemasaran.

Pada situasi demikian perlu dilakukan usaha-usaha promosi untuk menguasai informasi dan keadaan pasar dimana seorang manejer pemasaran dapat memilih dari beberapa metode promosi seperti: periklanan (advertising), penjualan perseorangan (personal selling), publisitas (publicity), promosi penjualan (sales promotion), dan lainnya, dimana tujuan seluruh usaha organisasi dalam pemasaran adalah untuk meningkatkan penjualan yang dapat menghasilkan laba bagi perusahaan dengan cara menawarkan kebutuhan (jasa) yang memuaskan kepada pasar dalam jangka panjang.

Personal selling sebagai salah satu bauran dalam komunikasi pemasaran terpadu, dianggap sebagai salah satu cara yang paling efektif untuk mendekatkan diri antara produk perusahaan dan konsumennya karena bauran ini memfokuskan pada kegiatan pemasaran secara tatap muka atau langsung (face to face).

Personal selling memacu perusahaan untuk lebih mengenal pelanggan secara langsung, sehingga berdampak pada terkumpulnya informasi motif pembelian (taste) dan bentuk keinginan-keinginan lain. Melalui personal selling konsumen akan memperoleh informasi yang memadai melalui sales person yang ditugaskan secara khusus oleh perusahaan. Keberadaan televisi telah menjadi salah satu produk hiburan dan informasi yang paling mudah dijangkau masyarakat dan biasanya pasti ada dan dimiliki di setiap kehidupan konsumen. PT. Sibayak Entertainment Indonesia (PT. SEI) melihat peluang bahwa adanya kesulitan memperoleh siaran televisi nasional dengan antena biasa untuk daerah-daerah dataran tinggi karena frekuensi siar tidak mencapai daerah tersebut, jika ingin tetap dapat menonton maka harus membeli sebuah antena parabola biasa dengan siaran terkadang diacak atau layar biru.

PT. Sibayak Entertainment Indonesia adalah salah satu perusahaan yang menjual produk Siaran TV kabel atau yang biasa disebut siaran TV Digital yang memilih pasar Kabupaten Karo Propinsi Sumatera Utara. Perusahaan ini menawarkan 49 jenis siaran yang terdiri dari siaran lokal, dan siaran luar. Keberadaan Siaran TV Digital ini sangat diminati masyarakat kalangan menengah kebawah tidak terkecuali masyarakat kalangan atas, karena harganya relatif murah 
dibandingkan dengan produk TV kabel lainnya, dengan metode pembayaran dilakukan setiap sekali dalam satu bulan dan langsung dikutip oleh sales person perusahaan tersebut atau melalui perantara e-money dan melalui jalur Bank Transfer.

Sales person melakukan penjualan langsung dengan cara bergerak kelapangan (pasar) dengan melayani konsumen dari toko-toko yang berbentuk grosir maupun eceran, kedai ke kedai penjual makanan dan minuman, ada juga dengan mendatangi konsumen dari rumah ke rumah dan dari kantor ke kantor yang berada di Kabupaten Karo. Tujuan PT. SEI melakukan metode promosi personal selling untuk:

1. Menyampaikan Produk.

Personal Selling PT. SEI melakukan direct selling: menyampaikan informasi tentang SEI TV tentang produk siaran, kuliatas siaran, harga, sampai pemasangan, sehingga pembeli tertarik untuk berlangganan.

2. Meningkatkan penjualan

Kegiatan personal selling merupakan salah satu alat promosi yang dominan dan dapat dikuasai oleh perusahaan untuk mempengaruhi volume penjualan, maka PT. Sibayak Entertainment Indonesia melaksanakan personal selling dengan tujuan untuk meningkatkan penjualan. Melalui personal selling dapat membangkitkan minat calon pembeli untuk berlangganan dengan SEI TV.

3. Menghadapi persaingan

PT. Sibayak Entertainment Indonesia melakukan promosi personal selling untuk dapat menghadapi persaingan dari pesaingnya. Dengan melihat segala kemungkinan yang dapat terjadi, juga mempelajari segala kekuatan dan kelemahan dari pesaing maka dengan kemampuan yang ada perusahaan melalui sales person berusaha membangkitkan minat pembeli konsumen.

Walaupun telah menggunakan strategi promosi personal selling, namun diketahui bahwa target penjualan SEI TV dalam sehari yang harus dicapai adalah sebanyak 5 pelanggan, sedangkan dalam satu bulan harus mencapai 100 pelanggan. Tetapi saat ini personal selling yang digunakan tidak berjalan efektif hal ini berdasarkan pada tabel data pelanggan seperti dibawah ini :

Tabel 1 Data Pelanggan Tahun 2014-2018

\begin{tabular}{|c|c|}
\hline Tahun & Pelanggan \\
\hline 2014 & 1.230 Orang \\
\hline 2015 & 1.200 Orang \\
\hline 2016 & 1.120 Orang \\
\hline 2017 & 1.100 Orang \\
\hline 2018 & 1.000 Orang \\
\hline
\end{tabular}

Sumber: PT. Sibayak Entertainment Berastagi (PT. SEI)

Data pelanggan ini mewakili jumlah penjualan, karena setiap pelanggan dipandang sebagai hasil sekali penjulan. Berdasarkan data tabel di atas, diperoleh penjualan produk TV kabel terbanyak pada tahun 2014 dan tahun 2015. Data tersebut adalah data jumlah pelanggan setiap tahun.

Dalam data tersebut ada terjadi penurunan penjualan, hal ini dikarenakan adanya faktor-faktor, sebagai berikut: 
1. Adanya persaingan antar TV kabel seperti: TV Kabel Kabanjahe, Indovision, Transvision, BIG TV, Orange TV, Topas TV yang berpasar juga di Kabupaten Karo. Hal ini menuntut TV kabel untuk melakukan inovasi menciptakan sesuai dengan kebutuhan masyarakat setempat dengan ragam aneka siaran pilihan, sehingga setiap perusahaaan berlomba-lomba untuk menjadi yang terdepan, tercepat dan terbaik untuk memberikan pelayanan bagi konsumen.

2. Kurangnya tenaga sales person untuk menjual produk siaran PT. SEI TV di Kabupaten Karo. Sales person dalam sebuah perusahaan memiliki peranan yang sangat penting sebagai ujung tombak perusahaan dalam memaksimalkan keuntungan dan penjualan. Perusahaan akan memberikan target penjualan kepada sales person dengan harapan memiliki capaian yang tinggi untuk mencapai keberhasilan perusahaan. Salah satu tujuan utama sales person adalah mencapai penjualan produk berkelanjutan yang pada akhirnya untuk mempertahankan penjualan dalam jangka panjang sesuai dengan tujuan perusahaan. Kurangnya jumlah sales person mengakibatkan sulitnya untuk menjangkau daerah Kabupaten Karo

Salah satu faktor yang berperan penting dalam menopang perusahaan adalah capaian penjualan. Capaian penjualan selalu dapat dipandang sebagai hasil sales person mendekati dan melayani dengan baik pelanggannya. Tanpa adanya capaian penjualan yang baik perusahaan akan tertinggal dengan para pesaingnya.

Kemampuan sales person sebagai penopang dalam meningkatkan capaian penjualan harus diandalkan, semakin terampil sales person semakin berpeluang melakukan penjualan. Capaian penjualan menunjukkan seberapa besar prestasi yang dicapai dalam menjual produk siaran PT. SEI TV.

Capaian penjualan yang baik menunjukkan tingkat penjualan yang tinggi, meningkatnya jumlah penjualan baik dalam unit produk. Capaian penjualan PT. Sibayak Entertainment Indonesia harus ditingkatkan lagi dengan dipengaruhi oleh beberapa aspek kemampuan menjual karena dengan melihat kemampuan menjual di PT. Sibayak Entertainment Indonesia akan menghasilkan capaian yang baik pula dimana hal tersebut membawa keuntungan untuk kemajuan perusahaan. Berdasarkan latar belakang masalah yang sudah diuraikan, maka dapat dirumuskan masalah yang menjadi pokok bahasan penelitian ini adalah : Bagaimana interpretasi skor capaian penjualan produk siaran televisi PT. Sibayak Entertainment Indonesia dengan interpretasi skor dalam promosi secara personal selling?

Menurut William (2008) dalam Priansa (2017 : 220) "personal selling adalah interaksi antarindividu, saling bertemu muka yang ditujukan untuk menciptakan, memperbaiki, menguasai, atau mempertahankan hubungan pertukaran yang saling menguntungkan dengan pihak lain", sedangkan menurut Tjiptono dikutip dari Alfany dan Wijaksana (2016) personal selling adalah : "komunikasi langsung (tatap muka) antara penjual dan calon pelanggan untuk memperkenalkan suatu produk kepada calon pelanggan dan membentuk pemahaman pelanggan terhadap produk sehingga mereka kemudian akan mencoba dan membelinya". 
Adapun menurut Kotler dan Keller (2006) dalam Vinsensius (2011 : 251)"penjualan personal (personal selling) sebagai interaksi tatap muka dengan seorang calon pembeli (prospective purchaser) atau lebih untuk tujuan membuat presentasi, menjawab pertanyaan-pertanyaan, dan memperoleh pesanan", sedangkan menurut Alma (2017 : 185) "personal selling is oral presentation in a conversation with one or more procpective customers for the purpose of make in sales". (Personal seling ialah presentasi lisan dalam percakapan dengan satu atau lebih pelanggan prospektif untuk tujuan penjualan).

Pendapat lain menurut Hermawan (2012:106) "penjualan personal (personal selling) adalah pemasaran produk atau jasa di mana penjual bertemu langsung dengan pembeli untuk menjajaki prospek (peluang) pembelian". Lain halnya menurut Robinson dalam Winardi (2018 : 113) "personal selling sebagai interaksi antar pribadi, dan secara tatap muka untuk mencapai tujuan menciptakan, memodifikasi, mengeksploitasi atau mengusahakan timbulnya suatu hubungan pertukaran yang saling menguntungkan dengan pihak yang lain".

Aktivitas personal selling memiliki beberapa fungsi sebagai berikut :

1. Prospecting

Prospectingselling berfungsi untuk mencari dan mendapatkan konsumen baru serta menjalin hubungan yang baik dan positif dengan mereka secara berkelanjutan.

2. Targetting

Personal selling berfungsi untuk mengalokasikan berbagai potensi yang dimiliki oleh perusahaan dalam rangka memperoleh konsumen.

3. Communicating

Personal selling berfungsi untuk memberikan informasi yang mengenai produk perusahaan kepada konsumen sehingga konsumen memperoleh pengetahuan yang cukup tentang produk tersebut.

4. $\quad$ Selling

Personal selling berfungsi untuk mendekati, mempresentasikan dan mendemonstrasikan, mengatasi penolakan, serta menjual, produk kepada pelanggan. Penjual tersebut merupakan sumber profit bagi perusahaan.

5. Servicing

Personal selling berfungsi untuk memberikan berbagai jasa dan pelayanan kepada pelanggan sehingga pelayanan yang dirasakan oleh konsumen dapat dirasakan lebih optimal.

6. Information gathering

Personal selling berfungsi untuk melakukan riset dan inteligen pasar dan informasi yang diperoleh akan dijadikan sebagai sumber data bagi pengambilan keputusan bagi perusahaan dan atau pemasar.

7. Allocating

Personal selling berfungsi untuk menentukan konsumen yang akan dituju oleh perusahaan dan memaksimalkan produk yang dijual oleh perusahaan.

Menurut Assauri (2004) dalam Priansa (2017 : 222) tujuan dari personal selling adalah :

1. Mengadakan analisis pasar 
Termasuk mengadakan peramalan tentang penjualan yang akan datang, mengetahui dan mengawasi para pesaing dan memerhatikan lingkungan social dan ekonomi.

2. Menentukan calon konsumen

Mencari calon konsumen yang potensial, menciptakan pesanan baru dari konsumen yang sudah ada serta mencari tahu keinginan pasar secara lebih mendalam.

3. Mengadakan komunikasi

Komunikasi merupakan tujuan yang paling utama dari penjualan perseorangan.Tujuan di sini tidakla hmenitik beratkan untuk membujuk atau memengaruhi, tetapi memulai dan melangsungkan pembicaraan secara ramah tamah kepada pelanggan atau calon konsumen. Komunikasi yang bersifat membujuk hanya merupakan salah satu elemen saja dari fungsi komuikasi.

4. Memberikan pelayanan

Dapat diwujudkan dalam bentuk konsultasi menyangkut keinginan dan masalah-masalah yang dihadapi pelanggan, memberikan jasa teknis, memberikan bantuan keungan, misalnya berupa bantuan kredit dan melakukan pengiriman barang sampai ketempat pemesanannya.

5. Memajukan pelanggan

Dalam mewujudkan pelanggan, tenga penjual bertanggung jawab atas semua tugas langsung yang berhubungan dengan pelanggan. Hal ini dimaksudkan untuk menguraikan tugasnya agar dapat meningkatkan keuntungan. Dalam tujuan ini termasuk juga memberikan saran secara pribadi, misalnya saran tentang masalah pengawasan persediaan, promosi, pengembangan produk, dan kebijakan harga. Dengan memajukan pelanggan dimaksudkan penjual diharapkan dapat meningkatkan volume penjualan.

Pada dasarnya dalam melakukan penjualan, sales person harus memahami prinsip-prinsip personal selling. Menurut Alma (2016 : 186) prinsip-prinsip dasar personal selling adalah :

1. Persiapan yang matang, meliputi pengetahuan :

a. Mengenal pasar dimana barang akan dijual yang meliputi keteranganketerangan mengenai keadaan perekonomian pada umummnya, persaingan, trend harga dan sebagainya.

b. Mengenali langganan dan calon langganan. Dalam hal ini perlu diketahui buying motives yaitu apa motif orang membeli dan buying habitsyaitu kebiasaan orang membeli. Buying habits orang kita, biasanya suka memborong belanja barang pada awal tiap bulan, pada hari-hari menjelang hari raya, tahun baru dan sebagainya.

c. Cukup mengetahui tentang produk yang akan dijualnya. Para konsumen sangat tidak senang pada penjual, yang tidak bisa menjawab pertanyaan-pertanyaan konsumen, sebagaimana biasanya konsumen mendapatkan macam informasi mengenai barang yang akan dibelinya.

d. Prinsip dasar harus dikuasai oleh penjual karena dengan demikian ia dapat mempengaruhi konsumen untuk membuat transaksi yang 
mengguntungkan kedua belah pihak. Ia berusaha dengan segala kemampuannya agar konsumen yang ingin membeli produk, harus selalu mempunyai kesan baik, dan bisa melakukan trnsaksi yang mengguntungkan kedua belah pihak.

2. Mendapatkan atau menentukan tempat pembeli

Dalam mendapatkan pembeli, seorang penjual harus berpedoman kepada kebijaksanaan perusahaan mengenai channel of distribution yang dipergunakan.

3. Merealisasikan penjualan

Meskipun dimana terjadinya penjualan tersebut beraneka ragam tetapi langkah-langkah yang diambil oleh penjual dalam proses penjualan adalah
a. Pendekatan dan pemberian hormat.
b. Penentuan kebutuhan langganan.
c. Menyajikan barang dengan efektif.
d. Mengatasi keberatan-keberatan.
e. Melaksanakan penjualan-penjualan.

4. Menimbulkan goodwill setelah penjulan terjadi

Jika penjualan terjadi dengan baik, maka pembeli akan memperoleh laba. Hal ini akan mempunyai pengaruh baik terhadap pembeli tersebut, yaitu akan membeli lagi kepada penjual yang sama di kemudian hari.

Personal selling dilakukan dengan komunikasi dua arah antara sales person dan konsumen yang memungkinkan pesan-pesan penjualan disesuaikan dengan lingkungan dan kondisi konsumen. Beberapa bentuk personal selling adalah sebagai berikut :

1. Field Selling, yaitu bentuk aktivitas personal selling yang dilakukan dengan cara menyebarkan para sales person ke rumah-rumah atau kantorkantor.

2. Retail Selling, yaitu bentuk aktivitas personal selling yang dilakukan oleh sales person yang bertugas untuk melayani konsumen yang datang ke toko atau perusahaan.

3. Excutive Selling, yaitu bentuk aktivitas personal selling yang kadangkadang menempatkan pimpinan perusahaan sebagai sales person.

Menurut Kotler dan Amstrong (2012) dalam Priansa (2017 : 229) bahwa ada tujuh teknik-teknik dalam personal selling yaitu :

1. Memilih calon pelanggan (personal and qualifying)

Langkah pertama dalam personal selling adalah mengidentifikasi dan memilih calon pelanggan. Beberapa perusahaan terlebih dahulu melakukan hal tersebut agar sales person mampu menggunakan waktu mereka yang berharga untuk melakukan yang terbaik yaitu penjualan (selling). Perusahaan terlebih dahulu memilih calon konsumen dengan menghubungi mereka melalui e-mail atau telepon untuk memperoleh tingkat ketertarikan dan kemampuan keuangan mereka. Hot prospect akan dilimpahkan langsung kepada sales person lapangan, sedangkan untuk warm prospect dilimpahkan kepada telemarketing untuk di- follow-up kembali.

2. Mempelajari calon konsumen (preapproach) 
Sales person perlu mempelajari semua tentang prospect (kebutuhan, karakteristik konsumen, gaya hidup konsumen). Jika prospect adalah perusahaan, kita perlu mempelajari proses pembeliannya, struktur pembeliannya, pengambil keputusan pembelian, apakah departemen pembelian bersifat centralized purchasing atau decentralizing purchasing. Sales person harus mengerti ketentuan dan proses pembelian yang berkenaan dengan who, when, how, and why, agar bisa mengatur strategi dan mendapatkan penjualan.

3. Pendekatan (approach)

Ini merupakan proses personal selling, yaitusales person bertemu dan menyapa konsumen untuk memperoleh hubungan atau memulai suatu awal yang baik. Langkah ini melibatkan penampilan sales person, katakata pembukaan yang menarik, serta penjelasan lanjut.

4. Presentasi dan Peragaan (presentation and demonstration)

Ini merupakan proses personal selling, yaitu sales person menceritakan riwayat produk kepada konsumen, dengan menjelaskan features, advantages, benefits, dan value. Features menguraikan tentang karakteristik dari produk yang ditawarkan. Advantages menguraikan bagaimana features memberikan manfaat bagi konsumen. Benefits menguraikan keuntungan dari sisi ekonomi, secara teknik, pelayanan, dan sosial. Value menguraikan tentang segala hal yang biasa didapat dibandingkan harga yang harus di bayar. Sales person biasanya menghabiskan waktu paling lama ketika menguraikan tentang features.

5. Mengatasi keberatan (overcoming objection)

Ini merupakan proses personal selling, yaitu sales person menyelidiki, mengklarifikasi, dan mengatasi keberatan konsumen untuk membeli. Selama presentasi, konsumen hampir selalu mempunyai keberatan. Demikian juga, sewaktu mereka diminta untuk menuliskan pesanan. Masalahnya bisa logis, bisa juga psikologis, dan keberatan saling tidak diungkapkan keluar. Dalam mengatasi keberatan, sales person harus menggunakan pendekatan positif, menggali keberatan yang tersembunyi, meminta konsumen untuk menjelaskan keberatan, menggunakan keberatan sebagai peluang untuk memberikan informasi lebih banyak, dan mengubah keberatan menjadi alasan membeli.Setiap sales person membutuhkan pelatihan dalam hal-hal keterampilan mengatasi keberatan. Langkah ini bisa berubah menjadi tahap positif dari proses penjualan karena menyediakan peluang kepada sales person untuk menyediakan informasiinformasi tambahan dan menawarkan solusi yang unik sebagai salah satu cara untuk mengklarifikasi berbagai keberatan yang muncul.

6. Menutup penjualan (closing)

Ini merupakan proses personal selling dengan cara sales person menanyakan apa yang akan dipesan oleh konsumen. Setelah mengatasi keberatan prospek, sales person dapat mencoba untuk menutup penjualan. Sales person harus mengetahui tanda-tanda penutupan dari konsumen, termasuk gerakan fisik, komentar, ataupun pertanyaan.

7. Tidak lanjut setelah penjualan dan perawatan (follow-up and maintenance) 
Follow-up dan maintenance diperlukan untuk memberikan kepuasan konsumen yang paripurna sehingga mampu menopang bisnis perusahaan berkelanjutan. Setelah penjualan terjadi, sales person harus memerhatikan dan memastikan jadwal pengiriman dengan baik dan tepat waktu, ketentuan pembelian yang dipersyaratkan yang di dalamnya termasuk garansi yang diberikan, serta hal-hal penting lainnya yang perlu diinformasikan kepada konsumen.Setelah pengiriman, sales person harus membuat jadwal follow-up untuk memastikan pemasangan, pemakaian, instruksi, dan mendeteksi masalah agar konsumen semakin yakin terhadap kecakapan sales person dalam memuaskan kebutuhannya. Dengan demikian, pada masa yang akan datang, konsumen tersebut akan membeli barang kembali dalam jumlah yang lebih besar dan memberikan rekomendasi yang baik untuk orang lain.

Pelaksanaan personal selling membutuhkan dukungan dari pegawai yang berkompetensi dalam bidang penjualan. Menurut Priansa (2017 : 232) ada tiga yang menjadi indikator personal selling dalam meningkatkan minat konsumen untuk melakukan pembelian, yaitu :

1. Salesmanship

Salesmanship merupakan kompetensi yang sekaligus menunjukkan loyalitas sales person, kualitas produk yang dijual, atau peranan sales person dalam pendekatan kepada seseorang atau orang lain sehingga dapat membentuk titik keputusan untuk menetapkan hak utama sebagai individu, dalam penetapan kesempatan milik atau minat. Sales person harus memiliki pengetahuan tentang produk dan menguasai seni menjual, seperti cara mendekati pelanggan, memberikan presentasi dan demonstrasi, mengendalikan diri ketika konsumen memberikan penolakan, serta memengaruhi dan mendorong konsumen untuk melakukan pembelian.

2. Negotiating

Sales person harus memiliki kompetensi dalam hal melakukan negoisasi penjualan dengan konsumen, baik terkait dengan program-program perusahaan maupun syarat-syarat pembelian yang berlaku. Negoisasi biasanya dilakukan tidak hanya berhubungan dengan harga, tetapi mengenai jumlah volume yang dipesan, detail kontrak, risiko-risiko yang mungkin terjadi dikedua belah pihak.

3. Relationship marketing

Sales person harus mengetahui secara detail cara untuk membina dan memelihara hubungan yang baik dengan konsumen. Relationship marketing mendorong kemitraan antara perusahaan/pemasar dan pelanggan secara terus-menerus, yang pada akhirnya akan menimbulkan kestiaan pelanggan sehingga terjadi bisnis ulangan (repeat business)

Menurut Rangkuti (2009 : 57) penjualan adalah "pemindahan hak milik atas barang atau pemberian jasa yang dilakukan penjualan kepada pembeli dengan harga yang disepakati bersama dengan jumlah yang dibebankan kepada pelanggan dalam penjualan barang/jasa dalam suatu periode akuntansi", sedangkan menurut Marwan dalam Sopiah (2016 : 1) kepenjualan adalah : "suatu usaha yang terpadu 
untuk mengembangkan rencana-rencana strategis yang diarahkan pada usaha memenuhi kebutuhan dan keinginan pembeli guna mendapatkanpenjualan yang menghasilkan laba". Penjualan yang dilakukan perusahaan bertujuan untuk menjual barang/jasa yang diperlukan sebagai sumber pendapatan untuk menutup semua ongkos untuk memperoleh laba.

Menurut Baldauft (2001) dikutip dari Syaeful Amri (2014) capaian penjualan adalah : "suatu evaluasi dari kontribusi tenaga penjualan untuk mencapai tujuan-tujuan organisasi". Capaian penjualan merupakan ukuran prestasi yang diperoleh dari proses aktivitas penjualan secara menyeluruh dari sebuah organisasi. Adapun menurut Yulianto (2002) dikutip dari Arafat (2013) capaian penjualan adalah: "hasil dari implementasi berbagai strategi penjualan yang dilakukan perusahaan".

Kegiatan penjualan dipengaruhi oleh beberapa faktor, yaitu :

1. Kondisi dan kemampuan penjualan

Transaksi jual-beli atau perpindahan hak milik secara komersial atas barang dan jasa itu pada prinsipnya melibatkan dua pihak, yaitu penjual sebagai pihak pertama dan pembeli sebagai pihak kedua. Di sini penjual harus dapat meyakinkan kepada pembelinya agar dpat berhasil mencapai sasaran penjualan yang diharapkan. Untuk maksud tersebut penjual harus memahami beberapa masalah penting yang berkaitan, yakni :

a. Jenis dan Karakteristik barang yang ditawarkan.

b. Harga produk.

c. Syarat penjualan

2. Kondisi Pasar

Pasar sebagai kelompok pembeli atau pihak yang menjadi sasaran dalam penjualan, dapat pula mempengaruhi kegiatan penjualannya. Adapun faktor-faktor kondisi pasar yang perlu diperhatikan adalah :

a. Jenis pasarnya, apakah konsumen, pasar industri, pasar penjual, pasar pemerintah, atukah pasar internasional

b. Kelompok pembeli atau segmen pasarnya

c. Daya belinya

d. Keinginan dan kebutuhannya

3. Modal

Akan sulit bagi penjual untuk menjual barangnya apabila barang yang dijual tersebut belum dikenal calon pembeli atau apabila lokasi pembeli jauh dari tempat penjual. Dalam keadaan seperti penjual harus memperkenalkan dulu, membawa barangnya ke tempat pembeli. Untuk melaksanakan maksud tersebut diperlukan adanya sarana serta usaha seperti : alat transportasi, tempat peragaan baik di dalam perusahaan maupun di luar perusahaan, usaha promosi dan sebagianya. Semua ini hanya dapat dilakukan apabila penjual memiliki sejumlah modal yang diperlukan.

4. Kondisi Organisasi Perusahaan

Pada perusahaan besar, biasanya masalah penjualan ini ditangani oleh bagian tersendiri (bagian penjualan) yang dipegang orang-orang tertentu/ahli di bidang penjualan. 
Menurut Winardi (2018 : 15) ada tiga macam tujuan umum yang melandasi capaian penjualan, yaitu :

1. Mencapai volume penjualan tertentu

Perusahaan harus memperhatikan bauran pemasaran dan memiliki strategi pemasaran yang baik untuk memasarkan produknya untuk mencapai penjualan yang tinggi. Kemampuan perusahaan dalam menjual produknya menentukan keberhasilan dalam mencari keuntungan, apabila perusahaan tidak mampu menjual maka perusahaan akan mengalami kerugian.

2. Memberikan sumbangsih berarti ke arah pencapaian laba

Kemampuan perusahaan untuk menghasilkan laba akan dapat menarik para investor untuk menanamkan dananya guna memperluas usahanya, sebaliknya tingkat profitabilitas yang rendah akan menyebabkan para investor menarik dananya.

3. Mengupayakan pertumbuhan yang berkesinambungan

Kemampuan perusahaan untuk menjual produknya akan meningkatkan volume penjualan bagi perusahaan yang dapat menghasilkan keuntungan bagi perusahaan untuk menunjang pertumbuhan perusahaan dan akan tetap bertahan di tengah persaingan yang semakin ketat antar perusahaan.

Dalam penelitian yang dilakukan oleh Yudit Supriawardhana yang berjudul "Pengaruh Personal Selling Terhadap Volume Penjualan Produk Indihome (Studi Pada PT. Telkom Witel Semarang)". Berdasarkan hasil uji hipotesis yang telah dilakukan diketahui bahwa proses personal selling berpengaruh signifikan terhadap volume penjualan produk indihome di PT. Telkom Witel Semarang. Sedangkan berdasarkan hasil uji koefisien determinasi, diketahui bahwa besarnya pengaruh proses personal selling terhadap volume penjualan adalah sebanyak $52,6 \%$ dan sisanya sebesar $47,4 \%$ dipengaruhi oleh variabel lain yang diteliti dalam penelitian ini.

Dalam penelitian yang dilakukan oleh Yuhensia, dkk yang berjudul "Analisis Pengaruh Personal Selling, Publicity dan Advertising Terhadap Volume Penjualan Pada Produk Komestik Oriflame di Sidoarjo". Hasil pengujian terbukti bahwa variabel personal selling, publicity, dan advertising berpengaruh secara simultan yang signifikan dengan hasil regresi linear berganda dalam uji $\mathrm{F}$ diperoleh $\mathrm{F}$ hitung sebesar 117.566 lebih besar dari $t$ diperoleh $t_{\text {hitung }}$ untuk masing-masing variabel bebas yaitu variabel personal selling (X1) sebesar 9.460, publicity (X2) sebesar 7.021, dan advertising (X3) sebesar 4.987 lebih besar dari nilai $\mathrm{t}_{\text {tabel }}$ sebesar 1.656, maka variabel bebas yaitu personal selling, publicity, dan advertising berpengaruh terhadap variabel terikat volume penjualan, sedangkan variabel personal selling berpengaruh dominan terhdap volume penjualan.

Berdasarkan uraian teoritis bahwa kegiatan personal selling salah satu metode promosi yang dominan dan dapat dikuasai perusahaan untuk mencapai capaian penjualan.

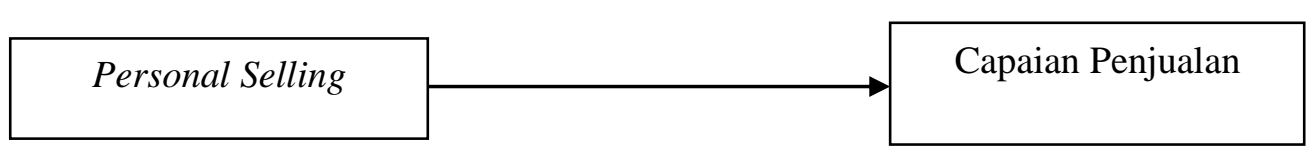

Gambar 1 Kerangka Berpikir 


\section{METODE PENELITIAN}

Penelitian ini mengacu pada penelitian deskriptif analisis kualitatif. Menggunakan cara kuesioner terhadap personal selling dan capaian penjualan, kemudian mendapatkan hasil skoring dari kuesioner kegiatan personal selling dan capaian penjualan untuk selanjutnya dijelaskan dan diukur setiap item (pernyataan).

Penelitian ini dilakukan di PT. Sibayak Entertainment Indonesia Jalan Teknol No. 18A Peceran-Berastagi. Penelitian ini dilakukan dari bulan Oktober 2020 sampai dengan Maret 2021. Populasi dalam penelitian ini adalah seluruh karyawan/karyawati yang bekerja pada PT. Sibayak Entertainment Indonesia yang berperan sebagai personal selling yang berjumlah 50 sales person. Sampel dalam penelitian ini adalah sampel jenuh dengan mengambil seluruh populasi berjumlah 50 sales person PT. Sibayak Entertainment Indonesia.

Dalam penelitian ini penulis menggunakan non probability sampling. Adapun cara pengambilan sampel dalam penelitian ini secara purposive sampling, dengan kriteria adalah sales person yang merupakan pelaku direct selling dalam personal selling.

a. Personal Selling.

Interaksi antar individu, saling bertemu muka yang ditujukan untuk menciptakan, mempertahankan hubungan pertukaran yang saling menguntungkan dengan pihak lain, dengan indikator:

1. Salesmanship.

2. Negotiating.

3. Relationship Marketing.

b. Capaian Penjualan.

Hasil dari implementasi berbagai strategi penjualan yang dilakukan perusahaan, dengan indikator:

1. Mencapai volume penjualan tertentu.

2. Memberikan sumbangsih berarti ke arah pencapaian laba.

3. Mengupayakan pertumbuhan yang berkesinambungan.

Skala pengukuran yang digunakan adalah skala sikap Likert. Indikator dijadikan tolak ukur untuk membuat suatu pernyataan yang disajikan dalam bentuk kuesioner untuk menghasilkan jawaban (skor) dari setiap responden.

Tabel 2 Skala Pengukuran Sikap

\begin{tabular}{|l|l|}
\hline Pernyataan & Skor \\
\hline Sangat Setuju & 5 \\
\hline Setuju & 4 \\
\hline Kurang Setuju & 3 \\
\hline Tidak Setuju & 2 \\
\hline Sagat Tidak Setuju & 1 \\
\hline \multicolumn{2}{l}{ Sumber : Sugiyono (2016) }
\end{tabular}

Data akan dianalisis secara deskriptif dengan cara mengukur hasil skor dari pernyataan yang dijawab responden tersebut dalam bentuk skor ideal, rekapitulasi skor, persentase dan interpretasi hasil dalam pembahasan. 
Skor ideal (skor bila seluruh jawaban responden jatuh pada jawaban hanya satu dari setiap skala sikap), merupakan bobot setiap skala ukuran sikap Likert (tabel-2) dikalikan dengan banyaknya jumlah responden atau sampel.

Rekapitulasi skor dilakukan dengan cara menjumlah seluruh skor menurut skala ukuran sikap Likert, yaitu: hasil kali jumlah jawaban responden SS, S, KS, TS dan STS terhadap bobot skor masing-masing, yaitu: 6, 4, 3, 2 dan $\mathbf{0}$, untuk mendapatkan jumlah jawaban setiap responden di setiap pernyataan.

Ukuran untuk rekapitulasi skor, adalah berdasarkan Skor Ideal, sebagai berikut:

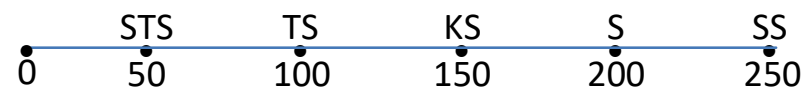

dimana,

0 s.d. 50 adalah daerah Sangat Tidak Setuju,

51 s.d. 100 adalah daerah Tidak Setuju,

101 s.d. 150 adalah daerah Kurang Setuju,

151 s.d. 200 adalah daerah Setuju,

201 s.d. 250 adalah daerah Sangat Setuju.

Hasil skor rekapitulasi digolongkan untuk melihat kekuatan dan kelemahan jawaban responden terhadap cara promosi dengan menggunakan personal selling dan capaian penjualan, dengan penggolongan sebagai berikut:

Angka 0\% s.d. $20 \%$ : Sangat Lemah

Angka 21\% s.d. $40 \%$ : Lemah

Angka $41 \%$ s.d. $60 \%$ : Cukup

Angka $61 \%$ s.d. $80 \%$ : Kuat

Angka $81 \%$ s.d. $100 \%$ : Sangat Kuat

\section{HASIL PENELITIAN DAN PEMBAHASAN}

Karakteristik responden berguna untuk mengetahui jawaban atas responden yang dilihat dari identitas responden. Hal ini terkait dengan ketepatan sasaran yang akan dituju. Karakteristik responden yang diamati dalam penelitian ini meliputi Jenis Kelamin, Umur, dan pendidikan disajikan sebagai berikut:

Tabel 3. Uji Validitas Personal Selling

\begin{tabular}{|c|c|c|c|}
\hline \multirow{2}{*}{ Pernyataan } & \multicolumn{2}{|c|}{ Nilai Validitas } & \multirow{2}{*}{ Keterangan } \\
\cline { 2 - 3 } & $\boldsymbol{R}_{\text {hitung }}$ & $\boldsymbol{R}_{\text {tabel }}$ & \\
\hline 1 & 0.436 & 0.278 & Valid \\
\hline 2 & 0.687 & 0.278 & Valid \\
\hline 3 & 0.501 & 0.278 & Valid \\
\hline 4 & 0.384 & 0.278 & Valid \\
\hline 5 & 0.612 & 0.278 & Valid \\
\hline 6 & 0.435 & 0.278 & Valid \\
\hline
\end{tabular}

Sumber data: Output SPSS

Dari hasil pengolahan data di atas dapat dilihat bahwa membandingkan $r$ hitung dan $r$ tabel keseluruhan pada personal selling, diambil kesimpulan bahwa pernyataan kuesioner dinyatakan valid. 
Tabel 4 Uji Validitas Capaian Penjualan

\begin{tabular}{|c|c|c|c|}
\hline \multirow{2}{*}{ Pernyataan } & \multicolumn{2}{|c|}{ Nilai Validitas } & \multirow{2}{*}{ Keterangan } \\
\cline { 2 - 3 } & $\boldsymbol{R}_{\text {hitung }}$ & $\boldsymbol{R}_{\text {tabel }}$ & \\
\hline 1 & 0.353 & 0.278 & Valid \\
\hline 2 & 0.615 & 0.278 & Valid \\
\hline 3 & 0.358 & 0.278 & Valid \\
\hline 4 & 0.605 & 0.278 & Valid \\
\hline 5 & 0.533 & 0.278 & Valid \\
\hline 6 & 0.606 & 0.278 & Valid \\
\hline
\end{tabular}

Sumber data: Output SPSS

Dengan melihat hasil terhadap capaian penjualan, hasil pengujian validitas menyatakan bahwa pernyataan kuesioner dapat disimpulkan bahwa adalah valid.

Tabel 5. Uji Reliabilitas

\begin{tabular}{|c|c|c|c|}
\hline Pernyataan & $\begin{array}{c}\text { Nilai Kriteria } \\
\text { Cronbach Alpha }\end{array}$ & $\begin{array}{c}\text { Nilai Regresi } \\
\text { Cronbach Alpha }\end{array}$ & Keterangan \\
\hline $\begin{array}{c}\text { Personal } \\
\text { Selling }\end{array}$ & & 0.691 & Realibel (Handal) \\
\cline { 1 - 3 } $\begin{array}{c}\text { Capaian } \\
\text { Penjualan }\end{array}$ & $\alpha=0.0600$ & 0.692 & Realibel (Handal) \\
\cline { 1 - 1 } Simultan & & 0793 & Realibel (Handal) \\
\cline { 3 - 4 } & & &
\end{tabular}

Sumber data: Output SPSS

Berdasarkan hasil pada kolom regresi Cronbach Alpha terhadap personal selling dan capaian penjualan, hasil pengujian ralibilitas (kehandalan) menyatakan bahwa memperhatikan nilai regresi Cronbach Alpha tersebut lebih besar dari nilai kriteria Cronbach Alpha, maka dinyatakan realibel (handal).

Analisis kategori variabel bertujuan untuk mengetahui gambaran masingmasing variabel penelitian yang disajikan dengan statistik deskriptif. Pada kuesioner tersebut terdapat 6 butir pernyataan untuk personal selling dan 6 butir pernyataan untuk capaian penjualan.

Berdasarkan desain penelitian dengan tebaran frekuensi, maka sumber informasi yang diperoleh dari jawaban responden dideskripsikan dalam bentuk nilai minimum, nilai maksimum, rata-rata dan standar deviasi.

Tabel 6 Statistik Deskriptif

\begin{tabular}{|l|c|c|c|c|c|c|}
\hline & N & Range & Minimum & Maximum & Mean & Std. Deviation \\
\hline Personal Selling & 50 & 11,00 & 18,00 & 29,00 & 25,3200 & 2,67597 \\
Capaian Penjualan & 50 & 10,00 & 20,00 & 30,00 & 24,8800 & 2,29142 \\
Valid N (listwise) & 50 & & & & & \\
\hline
\end{tabular}

Sumber: Data Primer yang diolah.

Dijelaskan demikian:

1. Personal Selling

Berdasarkan hasil pengumpulan data diperoleh nilai minimum untuk data personal selling sebesar 18 , nilai maksimum sebesar 29 dan nilai rata-rata sebesar 25,32 dengan standar deviasi sebesar 2,67597 .

2. Capaian Penjualan 
Berdasarkan hasil pengumpulan data diperoleh nilai minimum untuk variable capaian penjualan sebesar 20,00, nilai maksimum sebesar 30,00 dan nilai rata-rata sebesar 24,8800 dengan standar deviasi sebesar 2,29142.

Pembahasan bertujuan untuk melihat frekuensi dan persentase jawaban yang dipilih oleh responden atas setiap pernyataan yang terdapat dalam kuesioner.

1. Hasil Jawaban Personal Selling

Tabel 7 Penjelasan Responden terhadap Personal Selling

\begin{tabular}{|c|c|c|c|c|c|c|}
\hline \multirow{2}{*}{ Pernyataan } & \multicolumn{5}{|c|}{ Jumlah Responden } & \multirow{3}{*}{ Total } \\
\cline { 2 - 6 } & SS & S & KS & TS & STS & \\
\hline 1 & 14 & 25 & 9 & - & 2 & 50 \\
\hline 2 & 19 & 23 & 5 & 0 & 3 & 50 \\
\hline 3 & 27 & 17 & 2 & 3 & 1 & 50 \\
\hline 4 & 25 & 21 & 2 & 2 & - & 50 \\
\hline 5 & 21 & 20 & 8 & - & 1 & 50 \\
\hline 6 & 22 & 23 & 5 & - & - & 50 \\
\hline
\end{tabular}

Sumber: Data Primer Diolah, 2019

jawaban:

Dari tabel diatas dapat disimpulkan bahwa jika dilihat dari kriteria sangat setuju (SS), pernyataan satu merupakan pernyataan dengan tingkat persentase paling sedikit dijawab oleh sales person yang dapat dinyatakan bahwa sales person memiliki kemampuan menjelaskan kualitas PT. SEI TV untuk menarik minat pelanggan,

setuju (S), pernyataan tiga merupakan pernyataan yang paling sedikit dijawab oleh para responden, yang menyatakan bahwa sales person memiliki kemampuan untuk memberikan informasi terkait dengan harga, dan bagaimana sistem pembayarannya,

kurang setuju (KS), pernyataan tiga dan empat merupakan tingkat persentase yang paling sedikit dijawab oleh responden yang dapat disimpulkan bahwa sales person tidak melakukan kesepakatan dengan konsumen,

tidak setuju (TS), pernyataan empat merupakan tingkat persentase yang paling sedikit dijawab oleh responden, yang dapat dinyatakan bahwa sales person meyakinkan pelanggan dengan informasi yang telah disepakati,

sangat tidak setuju (STS), pernyataan satu merupakan tingkat persentase terbanyak yang dijawab oleh responden yang dapat disimpulkan bahwa sebagian besar sales person memiliki kemampuan menjelaskan kualitas PT. SEI TV untuk menarik minat pelanggan.

2. Hasil Jawaban Capaian Penjualan

Tabel 8. Penjelasan Responden terhadap Capaian Penjualan

\begin{tabular}{|c|c|c|c|c|c|c|}
\hline \multirow{2}{*}{ Pernyataan } & \multicolumn{5}{|c|}{ Jumlah Responden } & \multirow{3}{*}{ Total } \\
\cline { 2 - 6 } & SS & S & KS & TS & STS & \\
\hline 1 & 13 & 29 & 8 & - & - & 50 \\
\hline 2 & 13 & 27 & 8 & 2 & - & 50 \\
\hline
\end{tabular}




\begin{tabular}{|c|c|c|c|c|c|c|}
\hline 3 & 24 & 23 & 2 & - & 1 & 50 \\
\hline 4 & 7 & 22 & 19 & 1 & 1 & 50 \\
\hline 5 & 22 & 22 & 6 & - & - & 50 \\
\hline 6 & 27 & 17 & 5 & 1 & - & 50 \\
\hline
\end{tabular}

Sumber: Data Primer Diolah, 2019 jawaban:

Dari tabel diatas dapat disimpulkan bahwa jika dilihat dari kriteria sangat setuju (SS), pernyataan empat merupakan pernyataan dengan tingkat persentase paling sedikit dijawab oleh sales person yang dapat dinyatakan bahwa kemampuan menjual PT. SEI TV lebih dari jumlah yang ditargetkan perbulannya, setuju (S), pernyataan enam merupakan pernyataan paling sedikit dijawab oleh para responden yang dapat dinyatakan bahwa PT. SEI TV melakukan inovasi secara terus menerus untuk meningkatkan pertumbuhan perusahaan,

kurang setuju (KS), pernyataan tiga merupakan tingkat persentase yang paling sedikit dijawab oleh responden yang dapat disimpulkan bahwa responden PT. SEI TV membagikan brosur kepada masyarakat untuk memperkenalkan kepada calon konsumen,

tidak setuju (TS), pernyataan empat dan enam merupakan tingkat persentase yang paling sedikit dijawab oleh responden, yang dapat dinyatakan bahwa kemampuan menjual PT. SEI TV lebih dari jumlah yang ditargetkan perbulannya dan PT. SEI TV melakukan inovasi secara terus menerus untuk meningkatkan pertumbuhan perusahaan,

sangat tidak setuju (STS), pernyataan tiga dan empat merupakan tingkat persentase terbanyak yang dijawab oleh responden bahwa SEI TV membagikan brosur kepada masyarakat untuk memperkenalkan kepada calon konsumen dan kemampuan menjual PT. SEI TV lebih dari jumlah yang ditargetkan perbulannya.

Skor ideal merupakan batas nilai jawaban responden sampai dengan batas ukur skala sikap Likert dari bobot jawabannya.

Skor Ideal Sangat Setuju (SS): skor (5) x 50 jumlah responden $=250$

artinya: Bila seluruh jawaban adalah Sangat Setuju

Skor Ideal Setuju (S): skor (4) x 50 jumlah responden $=200$

artinya: Bila seluruh jawaban adalah Setuju

Skor Ideal Kurang Setuju (KS): skor (3) x 50 jumlah responden $=150$

artinya: Bila seluruh jawaban adalah Kurang Setuju

Skor Ideal Tidak Setuju (TS): skor (2) x 50 jumlah responden $=100$

artinya: Bila seluruh jawaban adalah Tidak Setuju

Skor Ideal Sangat Tidak Setuju (STS): skor (1) $\mathrm{x} 50$ jumlah responden $=50$ artinya: Bila seluruh jawaban adalah Sangat Tidak Setuju

\section{Rekapitulasi Data 50 Responden}

Personal Selling

Pernyataan 1: Sales Person memiliki kemampuan menjelaskan kualitas Produk PT. SEI TV untuk menarik minat pelanggan.

menjawab SS: 14 responden $\mathrm{x}$ (5) $=70$ 
menjawab S: 25 responden $\mathrm{x}(4)=100$

menjawab KS: 9 responden $\mathrm{x}$ (3) $=27$

menjawab TS: 0 responden $\mathrm{x}$ (2) $=0$

menjawab STS: 2 responden $x$ (1) $=\frac{2 \quad+}{199}$

Secara kontinum, skor 199 secara ideal terletak pada daerah Setuju.

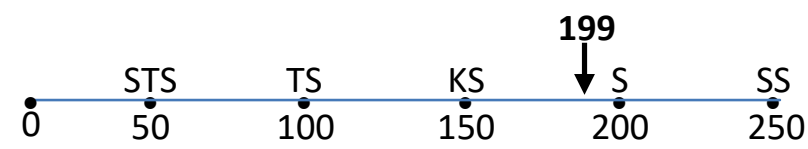

Pernyataan 2: Sales Person mendekati pelanggan, mempengaruhi, dan mendorong pelanggan untuk melakukan pembelian Produk PT. SEI TV.

menjawab SS: 19 responden $\mathrm{x}(5)=95$

menjawab S: 23 responden $x$ (4) $=92$

menjawab KS: 5 responden $\mathrm{x}$ (3) $=15$

menjawab TS: 0 responden $\mathrm{x}$ (2) $=0$

menjawab STS: 3 responden $x$ (1) $\frac{3+}{205}$

Secara kontinum, skor 205 secara ideal terletak pada daerah $\underline{\text { Sangat }}$ Setuju.

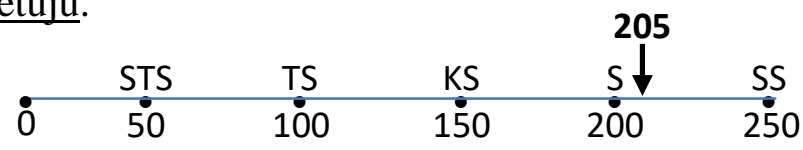

Pernyataan 3: Sales Person memiliki kemampuan untuk memberikan informasi terkait dengan harga, dan bagaimana sistem pembayarannya.

menjawab SS: 27 responden $x$ (5) $=135$

menjawab S: 17 responden $\mathrm{x}(4)=68$

menjawab KS: 2 responden $\mathrm{x}$ (3) $=6$

menjawab TS: 3 responden $x$ (2) $=6$

menjawab STS: 1 responden $\mathrm{x}(1)=\frac{1+}{216}$

Secara kontinum, skor 216 secara ideal terletak pada daerah $\underline{\text { Sangat }}$ $\underline{\text { Setuju. }}$

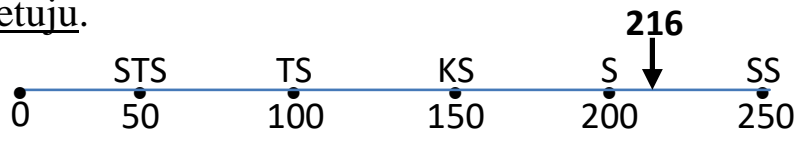

Pernyataan 4: Sales Person meyakinkan pelanggan dengan informasi yang telah disepakati dalam berlangganan.

menjawab SS: 25 responden $x$ (5) $=125$

menjawab S: 21 responden $x$ (4) $=84$

menjawab KS: 2 responden $\mathrm{x}$ (3) $=6$

menjawab TS: 2 responden $\mathrm{x}$ (2) $=4$ 
menjawab STS: 0 responden $\mathrm{x}(1)=\frac{0 \quad+}{219}$

Secara kontinum, skor 219 secara ideal terletak pada daerah Sangat Setuju.

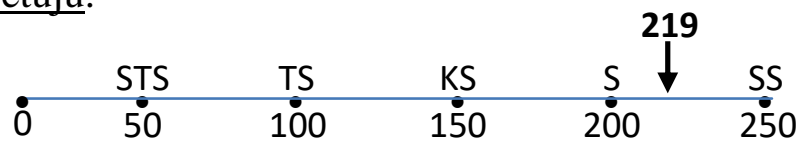

Pernyataan 5: Sales Person melakukan pelayanan kepada pelanggan dengan menerima keluhan para pelanggan PT. SEI TV.

menjawab SS: 21 responden $x$ (5) $=105$

menjawab S: 20 responden $x$ (4) $=80$

menjawab KS: 8 responden $x$ (3) $=24$

menjawab TS: 0 responden $\mathrm{x}(2)=0$

menjawab STS: 1 responden $\mathrm{x}(1)=\frac{1+}{215}$

Secara kontinum, skor 215 secara ideal terletak pada daerah $\underline{\text { Sangat }}$ Setuju.

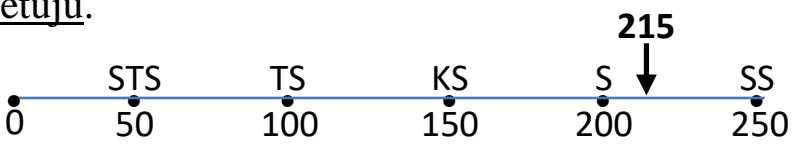

Pernyataan 6: Sales Person menyediakan informasi-informasi tambahan dan menawarkan solusi serta menjalin komunikasi yang baik kepada pelanggan.

menjawab SS: 22 responden $x$ (5) $=110$

menjawab S: 23 responden $x$ (4) $=92$

menjawab KS: 5 responden $\mathrm{x}$ (3) $=15$

menjawab TS: 0 responden $\mathrm{x}$ (2) $=0$

menjawab STS: 0 responden $x \frac{0 \quad+}{217}$

Secara kontinum, skor 217 secara ideal terletak pada daerah $\underline{\text { Sangat }}$ Setuju.

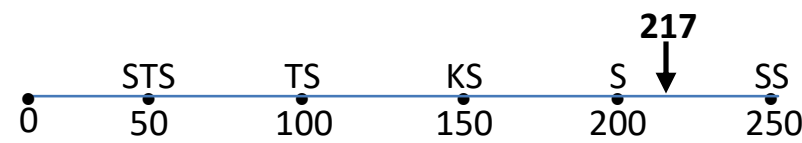

\section{Capaian Penjualan}

Pernyataan 1: PT. SEI TV melakukan promosi personal selling untuk mencapai target penjualan yang ditentukan.

menjawab SS: 13 responden $x$ (5) $=65$

menjawab S: 29 responden $x$ (4) $=116$

menjawab KS: 8 responden $\mathrm{x}$ (3) $=24$

menjawab TS: 0 responden $x$ (2) $=0$ 
menjawab STS: 0 responden $\mathrm{x}(1)=\frac{0 \quad+}{205}$

Secara kontinum, skor 205 terletak pada daerah Sangat Setuju.

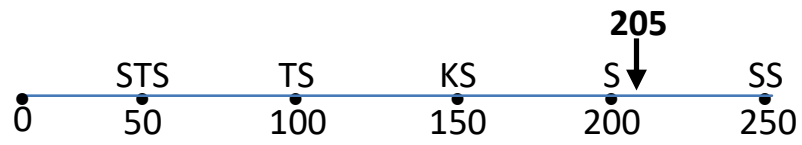

Pernyataan 2: PT. SEI TV memiliki strategi pemasaran yang baik untuk mencapai penjualan yang tinggi.

menjawab SS: 13 responden $x$ (5) $=65$

menjawab S: 27 responden $x$ (4) $=108$

menjawab KS: 8 responden $\mathrm{x}$ (3) $=24$

menjawab TS: 2 responden $x$ (2) $=4$

menjawab STS: 0 responden $x$ (1) $=\frac{0 \quad+}{201}$

Secara kontinum, skor 201 terletak pada daerah Sangat Setuju.

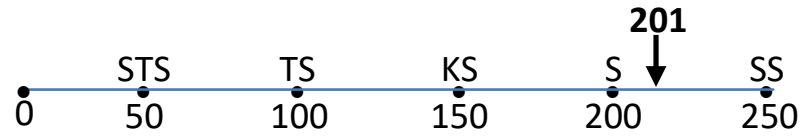

Pernyataan 3: PT. SEI TV membagikan brosur kepada masyarakat untuk memperkenalkan produk kepada calon konsumen.

menjawab SS: 24 responden $\mathrm{x}$ (5) $=120$

menjawab S: 23 responden $x$ (4) $=92$

menjawab KS: 2 responden $\mathrm{x}$ (3) $=6$

menjawab TS: 0 responden $\mathrm{x}$ (2) $=0$

menjawab STS: 1 responden $\mathrm{x}(1)=\frac{1 \quad+}{219}$

Secara kontinum, skor 219 terletak pada daerah Sangat Setuju.

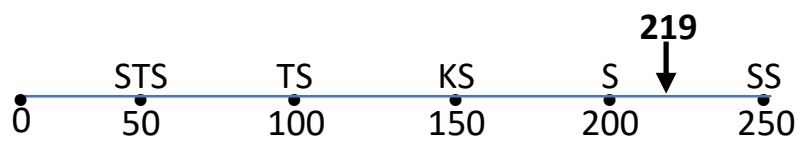

Pernyataan 4: Kemampuan menjual PT. SEI TV lebih dari jumlah yang di targetkan perbulannya.

menjawab SS: 7 responden $\mathrm{x}$ (5) $=35$

menjawab S: 22 responden $x$ (4) $=88$

menjawab KS: 19 responden $x$ (3) $=57$

menjawab TS: 1 responden $x$ (2) $=2$

menjawab STS: 1 responden $\mathrm{x}$ (1) $\frac{1+}{183}$

Secara kontinum, skor 183 terletak pada daerah $\underline{\text { Setuju. }}$ 


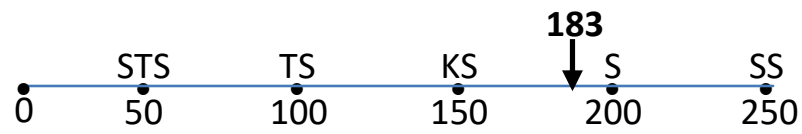

Pernyataan 5: Meningkatkan kualitas sinyal PT. SEI TV agar dapat bersaing dengan TV kabel lainnya.

menjawab SS: 22 responden $x$ (5) $=110$

menjawab $\mathrm{S}: \quad 22$ responden $\mathrm{x}(4)=88$

menjawab KS: 6 responden $\mathrm{x}$ (3) $=18$

menjawab TS: 0 responden $\mathrm{x}$ (2) $=0$

menjawab STS: 0 responden $\mathrm{x}(1)=\frac{0 \quad+}{216}$

Secara kontinum, skor 216 terletak pada daerah Sangat Setuju.

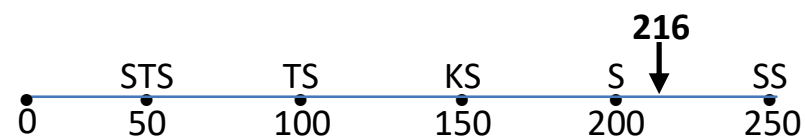

Pernyataan 6: PT. SEI TV melakukan inovasi secara terus menerus untuk meningkatkan pertumbuhan perusahaan.

menjawab SS: 27 responden $x$ (5) $=135$

menjawab S: 17 responden $x$ (4) $=68$

menjawab KS: 5 responden $\mathrm{x}$ (3) $=15$

menjawab TS: 1 responden $\mathrm{x}$ (2) $=2$

menjawab STS: 0 responden $x \frac{0 \quad+}{220}$

Secara kontinum, skor 220 terletak pada daerah Sangat Setuju.

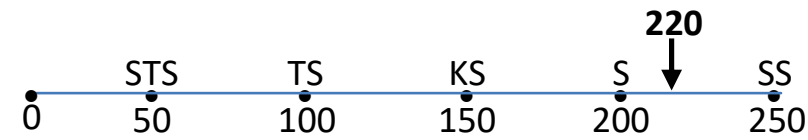

Persentase hasil rekapitulasi diukur dengan cara menghitung persentase rekapitulasi setiap pernyataan terhadap total skor bila seluruh jawaban adalah Sangat Setuju (SS) yaitu: (5) x $50=250$, kemudian dikategorikan letak kelemahan dan kekuatan secara:

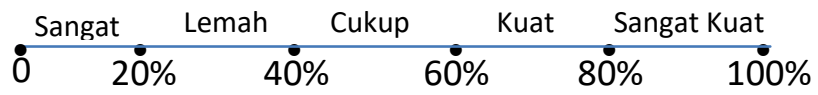

\section{Indikator Salesmanship}

Pernyataan 1: Sales Person memiliki kemampuan menjelaskan kualitas Produk

PT. SEI TV untuk menarik minat pelanggan.

Skor Rekapitulasi $=(199 / 250) \times 100 \%=79,6 \%$ 
Maka 79,6\% terletak di kategori KUAT.

Pernyataan 2: Sales Person mendekati pelanggan, mempengaruhi, dan mendorong pelanggan untuk melakukan pembelian Produk PT. SEI TV.

Skor Rekapitulasi $=(205 / 250) \times 100 \%=82 \%$

Maka $82 \%$ terletak di kategori SANGAT KUAT.

Indikator Negotiating

Pernyataan 3: Sales Person memiliki kemampuan untuk memberikan informasi terkait dengan harga, dan bagaimana sistem pembayarannya.

Skor Rekapitulasi $=(216 / 250) \times 100 \%=86,4 \%$

Maka $82 \%$ terletak di kategori SANGAT KUAT.

Pernyataan 4: Sales Person meyakinkan pelanggan dengan informasi yang telah disepakati dalam berlangganan.

Skor Rekapitulasi $=(219 / 250) \times 100 \%=87,6 \%$

Maka 87,6\% terletak di kategori SANGAT KUAT.

Indikator Relationship Marketing

Pernyataan 5: Sales Person melakukan pelayanan kepada pelanggan dengan menerima keluhan para pelanggan PT. SEI TV.

Skor Rekapitulasi $=(215 / 250) \times 100 \%=86 \%$

Maka $86 \%$ terletak di kategori SANGAT KUAT.

Pernyataan 6: Sales erson menyediakan informasi-informasi tambahan dan menawarkan solusi serta menjalin komunikasi yang baik kepada pelanggan.

Skor Rekapitulasi $=(217 / 250) \times 100 \%=86,8 \%$

Maka 86,8\% terletak di kategori SANGAT KUAT.

\section{Persentase Rekapitulasi Capaian Penjualan.}

Indikator Mencapai Volume Penjualan Tertentu

Pernyataan 1: PT. SEI TV melakukan promosi personal selling untuk mencapai target penjualan yang ditentukan.

Skor Rekapitulasi $=(205 / 250) \times 100 \%=82 \%$

Maka $82 \%$ terletak di kategori SANGAT KUAT.

Pernyataan 2: PT. SEI TV memiliki strategi pemasaran yang baik untuk mencapai penjualan yang tinggi.

Skor Rekapitulasi $=(201 / 250) \times 100 \%=80,4 \%$

Maka 80,4\% terletak di kategori KUAT.

Indikator Memberikan Sumbangsih Berarti Ke Arah Pencapaian Laba

Pernyataan 3: PT. SEI TV membagikan brosur kepada masyarakat untuk memperkenalkan produk kepada calon konsumen.

Skor Rekapitulasi $=(219 / 250) \times 100 \%=87,6 \%$

Maka 87,6\% terletak di kategori SANGAT KUAT.

Pernyataan 4: Kemampuan menjual PT. SEI TV lebih dari jumlah yang di targetkan perbulannya.

Skor Rekapitulasi $=(183 / 250) \times 100 \%=73,2 \%$

Maka 73,2\% terletak di kategori KUAT. 
Indikator Mengupayakan Pertumbuhan Yang Berkesinambungan

Pernyataan 5: Meningkatkan kualitas sinyal PT. SEI TV agar dapat bersaing dengan TV kabel lainnya.

Skor Rekapitulasi $=(216 / 250) \times 100 \%=86,4 \%$

Maka 86,4\% terletak di kategori SANGAT KUAT.

Pernyataan 6: PT. SEI TV melakukan inovasi secara terus menerus untuk meningkatkan pertumbuhan perusahaan.

Skor Rekapitulasi $=(220 / 250) \times 100 \%=88 \%$

Maka $88 \%$ terletak di kategori SANGAT KUAT.

\section{PEMBAHASAN}

Deskriptif berdasarkan hasil jawaban responden (Sub:4.5) analisis deskriptif pada personal selling diketahui bahwa pernyataan dengan indikator Salesmanship mampu dijelaskan dengan jawaban setuju, artinya PT. SEI TV sangat kuat dalam menarik minat pelanggan dan mendekati pelanggan dengan pendekatan sales person (walaupun ada yang sangt tidak setuju dengan langkah ssalesmanship ini).

Dalam Negotiating dengan sales person memiliki kemampuan sangat kuat memberikan informasi terkait dengan harga, dan bagaimana sistem pembayarannya (samahalnya, ada juga yang tidak setuju dan sangat tidak setuju terhadap metode negotiating ini). Relationship marketing yang dilakukan kepada pelanggan dengan langkah menerima keluhan para pelanggan PT. SEI TV menunjukkan langkah yang kuat dan sangat kuat. Langkah yang telah dilakukan pada salesmanship, negotiating dan relationship marketing berada pada kategori yang kuat dalam meningkatkan penjualan dikarenakan kemampuan direct selling secara personal selling yang dilakukan PT. SEI TV mampu menambah dan menarik minat berlangganan masyarakat. Dengan kata lain, hal ini menunjukkan bahwa personal selling dapat mempengaruhi penjualan PT. Sibayak Entertainment Indonesia.

Berdasarkan capaian penjualan, diketahui bahwa PT. SEI TV telah mencapai volume penjualan, yaitu rata-rata 5 pelanggan per hari atau 100 pelanggan per bulan atau 1200 pelanggan dalam satu tahun (Tabel-1, dilihat dari hasil yang dilakukan promosi personal selling untuk mencapai target penjualan). PT. SEI TV juga memiliki strategi pemasaran yang baik untuk mencapai penjualan yang tinggi dilihat dari jawaban setuju dan sangat setuju dalam capaian penjualan, artinya penjualan PT. SEI TV dapat meningkat karena adanya strategi pemasaran yang baik secara langkah mencapai volume penjualan tertentu, memberikan sumbangsih berarti ke arah pencapaian laba dan mengupayakan pertumbuhan yang berkesinambungan.

Dari keseluruhan deskriptif yang telah dilakukan dalam capaian penjualan dapat dinyatakan bahwa penjualan merupakan kegiatan yang mempunyai pengaruh besar terhadap PT. Sibayak Entertainment Indonesia. Menurut hasil Rekapitulasi dan Persentase Hasil Rekapitulasi, teknik promosi dengan personal selling dengan langkah negotiating dan realtionship marketing menunjukkan langkah yang sangat kuat dan merupakan langkah yang sangat disetujui, namun dalam langkah salesmanship masih ada keragu-raguan dari sales person dalam menjalankan metode "menjelaskan kualitas produk dan melakukan pendekatan" 
yang tidak berkategori kuat atau tidak sangat disetujui dalam meningkatkan penjualan PT. SEI TV. Lain hal dengan capaian penjualan yang menunjukkan langkah sangat kuat hanya pada teknik penjualan dengan cara "mengupayakan pertumbuhan yang berkesinambungan" yang merupakan langkah sangat disetujui untuk mencapai target penjualan dan mendorong sales person dengan cara personal selling dalam meningkatkan penjualan PT. SEI TV.

Sisanya, persentase hasil rekapitulasi skor jawaban dengan langkah penjualan "mencapai volume penjualan tertentu" dan "memberikan sumbangsih berarti ke arah pencapaian laba" sudah menunjukkan hasil yang sangat kuat, namun masih ada keragu-raguan sehingga beberapa hal menunjukkan kategori yang tidak diharapkan (kuat) yaitu pada saat mengejar target penjualan tertentu dan menentukan capaian laba tertentu dengan hasil jawaban yang setuju serta terdapat jawaban tidak setuju dan sangat tidak setuju. Tetapi hasil rekapitulasi dan persentase hasil rekapitulasi sudah menunjukkan bahwa PT. Sibayak Entertainment Indonesia telah mencapai target penjualan dan bila dilihat secara rata-rata penjualan (Tabel-1) dapat menunjukkan peningkatan walaupun adanya penurunan, tetapi penurunan ini tidaklah menunjukkan kelemahan yang mengganggu pertumbuhan dan perkembangan penjualan PT. SEI TV kedepan.

\section{KESIMPULAN}

Dari hasil penelitian tentang personal selling dan capaian penjualan pada PT. Sibayak Entertainment Indonesia, maka ditarik kesimpulan sebagai berikut:

1. Promosi dengan cara personal selling sudah menjadi langkah yang baik bagi PT. Sibayak Entertainment Indonesia, sebab seluruh sales person sudah menyatakan bahwa langkah-langkah personal selling sudah dilakukan oleh perusahaan.

2. Hasil penjualan PT. Sibayak Entertainment Indonesia sudah merupakan hasil penjualan yang baik, sebab capaian penjualan dengan ukuran: mencapai volume penjualan tertentu, memberikan sumbangsih berarti ke arah pencapaian laba dan mengupayakan pertumbuhan yang berkesinambungan sudah menunjukkan cara sangat baik dilakukan perusahaan dalam mencapai target penjualan 5 pelanggan sehari atau 100 pelanggan sebulan dan atau 1200 pelanggan dala setahun.

3. Bila dilihat hasil personal selling dan capaian penjualan dalam kurun waktu (tabel-1) terakhir tahu 2018, perusahaan cenderung mengalami penurunan capaian penjualan. Hal ini disebabkan adanya pesaing baru dan persaingan harga serta atribut produk dalam penjualan.

PT. Sibayak Entertainment Indonesia harus terus berusaha melakukan personal selling yang baik bila ditahun-tahun berikutnya tidak ingin mengalami penurunan capaian penjualan, dimana tahun terakhir (tahun penelitian) perusahaan hanya mencapai 1000 pelanggan. Bila dirata-ratakan, satu hari PT. Sibayak Entertainment Indonesia hanya dapat mencapai 3 pelanggan saja atau 84 pelanggan selama satu bulan.

PT. Sibayak Entertainment Indonesia harus dapat menguasai teknik-teknik personal selling. Sehingga diharapkan sales person akan lebih terampil dalam melakukan penjualan terhadap calon pelanggan. 


\section{DAFTAR PUSTAKA}

Alma, Buchari. 2017. Manajemen Pemasaran \& Pemasaran Jasa, Cetakan Keduabelas, Bandung. Alfabeta

Amri, Syaeful. 2014. Analisis Faktor-Faktor Yang Mempengaruhi Kinerja Tenaga Penjualan (Studi Pada PT. Nasmoco Jawa Tengah Dan DIY). Jurnal Sains Pemasaran Indonesia Vol. XIII, No. 3, Diakses pada tanggal 7 Maret 2019

Arafat, Rendy. 2013. Pengaruh Dimensi Sales Skil Terhadap Kinerja Penjualan. Management Analysis Journal, No. 2, Diakses pada tanggal 7 Maret 2019

Hermawan, Agus. 2012. Komunikasi Pemasaran. Jakarta. Erlangga

Kristanto, Vinsensius Jajat. 2009. Manajemen Pemasaran Internasional. Jakarta. Indeks

Nazir, M. 2011. Metode Penelitian, Cetakan Ketujuh. Bogor. Ghalia Indonesia

Priansa, Doni J. 2009. Komunikasi Pemasaran Terpadu, Cetakan Kesatu. Bandung. Pustaka Setia

Rangkuti, Freddy. 2009. Strategi Promosi Yang Kreatif \& Analisis Kasus Integrated Marketting Communication. Jakarta. Gramedia Pustaka Utama

Sopiah, Sangadji Etta Mamang. 2016. Salesmanship (Kepenjualan), Cetakan Pertama. Jakarta. PT. Bumi Aksara.

Sugiyono. 2010. Metode Penelitian Bisnis, Cetakan Kelimabelas. Bandung. Alfabeta.

Kedelapanbelas. Bandung. Alfabeta

Wahyudi, Alfany \& Wijaksana, T. I. 2016. Pengaruh Proses Personal Selling Terhadap Volume Penjualan Produk Indihome (Studi Pada PT. Telkom Witel Semarang). Jurnal e-Procceeding of Management Vol. 3, No. 2, Diakses pada tanggal 5 Desember 2018

Winardi. 2018. Pengantar Manajemen Penjualan (Sales Management), Cetakan Pertama. Bandung. PT.Citra Aditya Bakti.

Yuhensia, Dea, dkk. 2017. Analisis Pengaruh Personal Selling, Publicity Dan Advertising Terhadap Volume Penjualan Pada Produk Kosmetik Oriflame Di Sidoarjo . Jurnal Manajemen Branchmark Vol 3, Issue 3, Diakses pada tanggal 23 